\section{Premitotic Labeling and Inflammation in the Gingiva of Rhesus Monkeys}

by

\author{
Nikitas A. Demetriou,** D.D.S., M.S. \\ Sigurd P. RAMF JORD, ${ }^{*}$ L.D.S., PH.D.
}

THE PURPOSE OF THE present investigation was to study the often postulated relationship between mitotic activity and severity of inflammation in the gingival tissues. ${ }^{1,2}$ However, in order to carry out such a study, the premitotic activity in various separate zones of the gingival and crevicular epithelium had to be determined, and the degree of inflammation in the connective tissues adjacent to these various zones of the gingival epithelium had to be recorded in a quantitative way.

Mitotic activity of the oral epithelium has been studied by the count of mitotic figures, ${ }^{3-8}$ following colchicine administration $^{9,10}$ and more recently by autoradiographic techniques based on premitotic labeling. ${ }^{11-17}$ However, there is still a need for established values that can be used as baseline for normal mitotic activity of the various oral structures, mainly because of wide variations in experimental techniques, difference in species, influence of age, and circadian and sexual cycles.

Several attempts have also been made to develop quantitative reporting systems of the severity of gingival inflammation, ${ }^{18-22}$ but none of these numerical systems have enabled the investigator to relate specifically the severity of inflammation in one area of connective tissues to mitotic activity in the adjacent basal epithelial cells.

Since for safety reasons, radioactive labeling techniques cannot be used in humans, rhesus monkeys were used for the present study assuming that the biologic principles involved are fairly similar to humans.

\section{Material and Methods}

Three adult male rhesus monkeys were selected to avoid fluctuation in mitotic activity related to age ${ }^{17,23}$ and the estrus cycle in females. The monkeys had a full complement of the permanent teeth (including third mo-

The University of Michigan School of Dentistry, and the Veterans Administration Hospital, Ann Arbor, Michigan.

* Department of Periodontics, The University of Michigan School of Dentistry, Ann Arbor, Michigan 48104.

**3, Pindarou Street, Athens (134) Greece. lars). They initially had moderate amounts of supra and subgingival calculus, and generalized mild to moderate chronic marginal gingivitis. In order to standardize the experimental conditions, they were given a prophylaxis 2 weeks prior to the experiment.

One microcurie of tritiated thymidine (specific activity 6.7 curies per millimole*) per gram of body weight was administered intravenously in the three monkeys at 10:00 a.m., and they were all sacrificed one hour later to avoid diurnal changes. $3,9,17,22,24,25$ The jaws and teeth were fixed in buffered formalin, then divided into small block specimens of teeth and surrounding tissues which were decalcified in EDTA with $\mathrm{pH}$ adjusted to 7.4 .

Radioautographs ${ }^{26-32}$ were prepared from buccolingual sections in the plane of the long axis of the teeth. Some sections were stained with hematoxylin only, while in others both hematoxylin and eosin stains were used.

A total of 141 block sections from the three monkeys were included in this study.

The radioautographs were studied on the basis of dividing the gingival epithelium and adjacent alveolar mucosa into 5 zones as indicated in the schematic diagram (Figure 1):

a. Zone A (Figure 1) represents the entire epithelial attachment, which is subdivided into three zones of equal length; $A_{1}, A_{2}$, and $A_{3}$; with $A_{1}$ being situated immediately apically to the bottom of the gingival crevice and $A_{3}$ at the apical one third of the epithelial attachment. The division into subzones was done on the basis of sequential microscopical fields. ${ }^{4,20}$ Whenever the total number of microscopic field making up the epithelial attachment were not divisable by three the fields were assigned on a random basis; however, no more than one field was assigned to each one or two of the subzones. Thus the subzones $\left(A_{1}, A_{2}\right.$ and $\left.A_{3}\right)$ in the final analysis included approximately an equal number of microscopic fields.

b. Zone B (Figure 1) represents the crevicular epithelium, separated from the epithelial attachment by morphologic characteristics. ${ }^{29}$ (See Figure 2.)

c. Zone C (Figure 1) corresponds approximately to the outer surface of the free gingiva. Since a microscopic gingival groove ${ }^{33}$ is present only occasionally, the boundary between free and attached gingiva was considered to correspond to the bottom of the gingival crevice. (Figure 1.)

d. Zone D (Figure 1) corresponds to the surface of the attached gingiva.

e. Zone E (Figure 1) represents the alveolar mucosa.

*New England Nuclear Corporation, Boston, Massachusetts. 


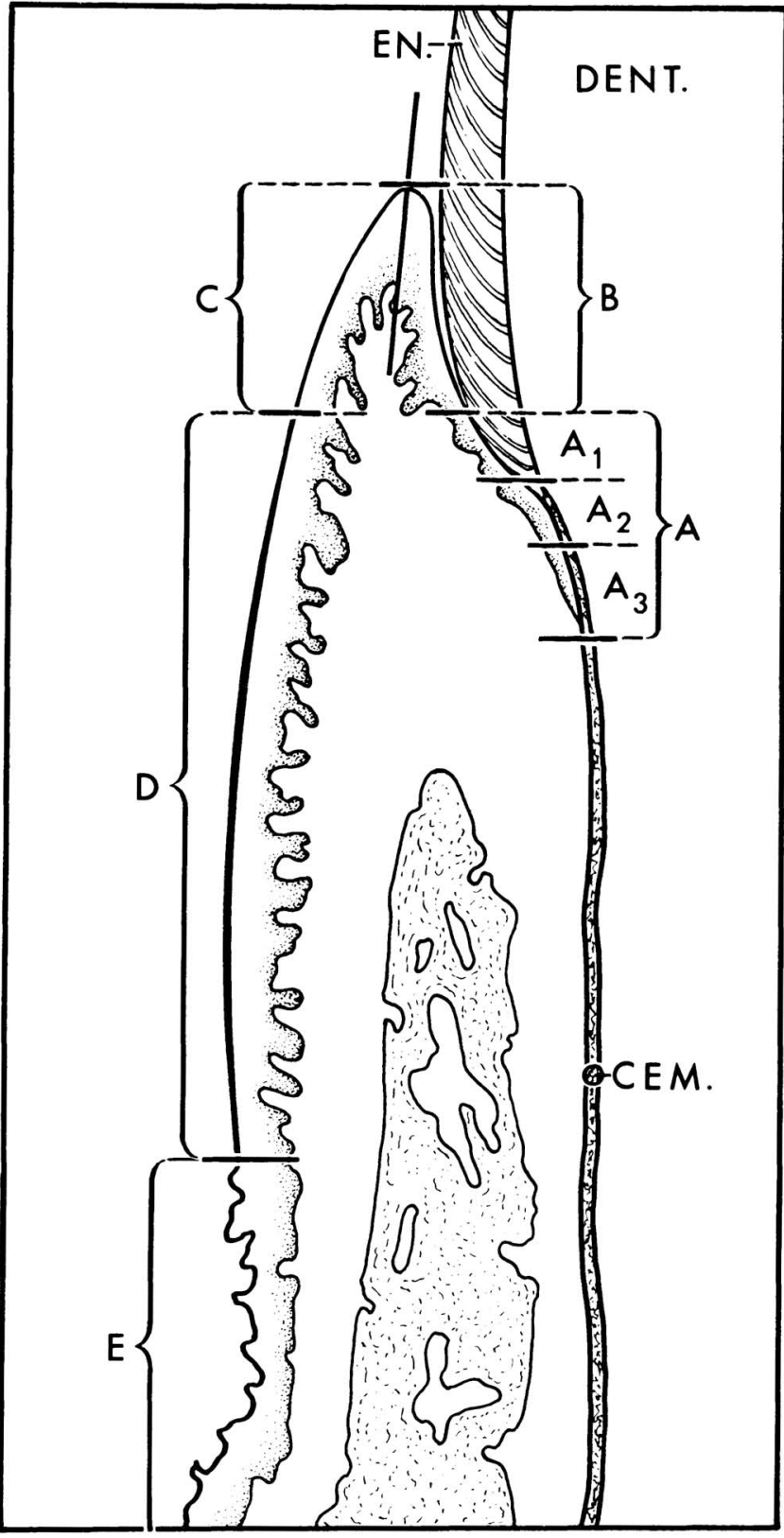

FIgURE 1. A diagram indicating the various zones that were studied. Zone $A$ is the epithelial attachments with subzones, $A_{1}$, being the crevicular one third of the attachment, $A_{2}$, the intermediate one third and $A_{3}$ the apical one third of the attachment. Zone $B$ is the crevicular epithelium. Zone $C$ is the outer surface of the attached gingiva. Zone $D$ is the surface of the attached gingiva. Zone $E$ is the alveolar mucosa.

Radioactive indices (RAI) and inflammatory indices (II) were determined for all 5 zones, and separate indices were calculated for the subzones. The radioactive indices were based on counting of all labeled and unlabeled basal cells in each microscopic field ( $X$ 1000 , with oil immersion and mechanical stage) and dividing the number of labeled cells by the total number of basal cells and multiplying by 100 . The decision

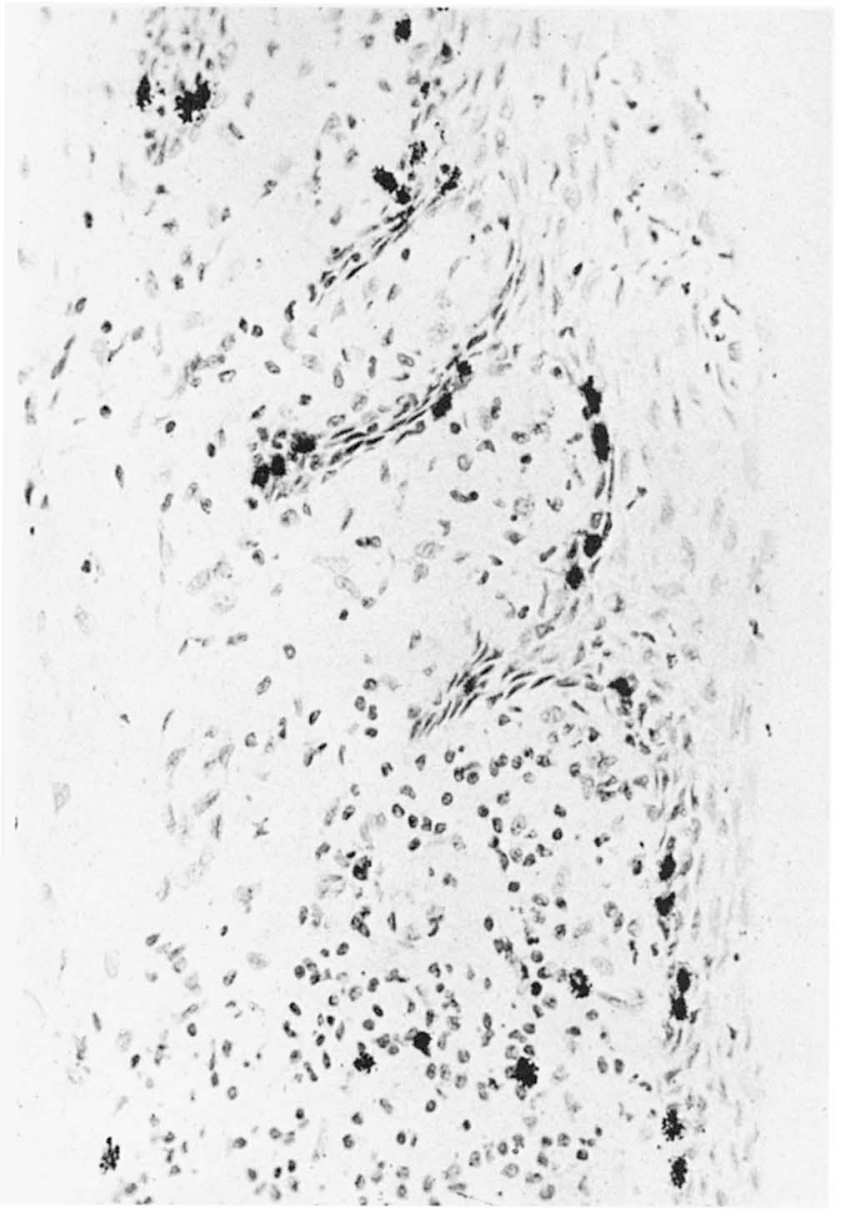

Figure 2. The junction between Zones $A$ and $B$ is at the middle of the photomicrograph. (Original magnification $\times$ 386).

to include only the basal cells was made to avoid differences in RAI on the basis of differences in thickness of the epithelium and thus not having a meaningful basis for comparison of the mitotic activities in the progenitor cells for each of the zones of the gingival epithelium.

The degree of severity of the chronic inflammation in the connective tissue adjoining the basal cell layer of the epithelium was determined on the basis of computation of an inflammatory index (II) as the ratio between the number of inflammatory cells and the total number of cells in the given field multiplied by 100 .

In order to compare the premitotic activity in the epithelium with the inflammatory activity in the adjacent connective tissues, the template aperture was positioned in such a way that the basal cells divided the whole microscopic field $(X 1000)$ into two approximately equal parts (Figure 3 ).

During the counting of cells, the template aperture was moved along the basal cells in zones A, B, and C, (Figure 1). For zone D, three sequential microscopic 


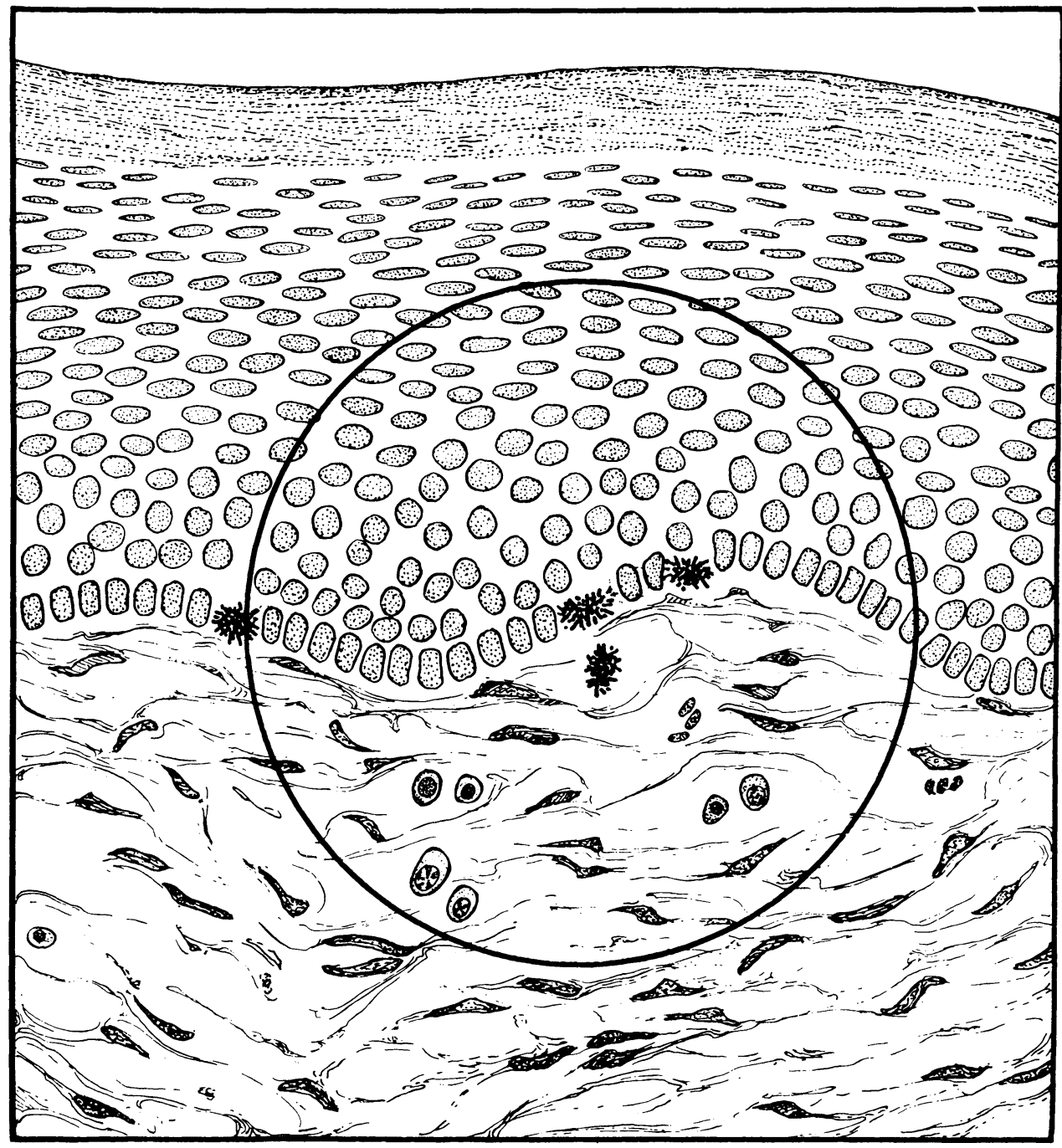

FIGURE 3. A diagram of the epithelial connective tissue junction with the circle indicating the selection of fields for the study.

fields were counted at each of the boundaries with zones $\mathrm{C}$ and $\mathrm{E}$, and three additional microscopic fields at the middle of zone D were counted whenever the zone was wide enough to do so.

At zone $\mathrm{E}$ (Figure 1) three sequential microscopic fields were counted starting at the boundary of zone D.

The mean values of RAI and II with standard deviations and standard errors were calculated for each of the zones and the subzones. The means of the two variables were actually means of section means, i.e. counts from a number of microscopic fields were averaged and a mean value for each section was calculated as well as the mean for the total number of section means for each zone.

\section{FindiNGS}

The radioactive indices (RAI) of the basal cells of the various zones of gingival and alveolar mucosal epithelium are listed in Table I. The highest rate of premitotic labeling was found in the crevicular epithelium $(\mathrm{RAI}=19.65)$, while the lowest activity was observed in the basal cells of the epithelial lining of the attached gingiva (zone D with RAI $=7.90$ ).

The premitotic activity in the three subzones of the epithelial attachment $\left(A_{1}, A_{2}\right.$ and $\left.A_{3}\right)$ is listed in Table 2 . There is a decrease in activity from the subzone closest to the gingival crevice (zone $\mathrm{A}_{1}$ with RAI 15.46) to the bottom one third of the epithelial attachment (zone $\mathrm{A}_{3}$ with $\mathrm{RAI}=8.28$ ).

The differences in RAI between the various zones of gingival epithelium were tested for statistical significance with the two way analysis of variance test and the Scheffe multiple comparison test. The results are shown in Table 3 which indicates that there is a statistically significantly higher value for premitotic activity in the crevicular epithelium than in the epithelial at- 
tachment $(\mathrm{p}<.001)$. The crevicular epithelium also shows significantly $(\mathrm{p}<.01)$ higher labeling than the outer surface of the free gingiva which again has a significantly higher rate of labeling $(p<.001)$ than the attached gingiva. The alveolar mucosa also has a significantly higher labeling index than the attached gingiva $(\mathrm{p}<.001)$

The analysis of differences of the mean RAI's for the subzones of the epithelial attachment are reported in Table 4 which indicates that the difference in RAI between the crevicular and apical subzones $\left(\overline{\mathrm{A}}_{1}-\overline{\mathrm{A}}_{3}\right)$ is highly significant $(\mathrm{p}<.001)$ and so is the difference between the middle and bottom third $\left(\overline{\mathrm{A}}_{2}-\overline{\mathrm{A}}_{3}\right)$ at $\mathrm{p}<.001$ while the difference between the upper and middle third $\left(\overline{\mathrm{A}}_{2}-\overline{\mathrm{A}}_{1}\right)$ is not significant.

The inflammatory indices (II) in the connective tissues corresponding to the zones of the premitotic epithelial labeling are listed in Table 5. The highest inflammatory index corresponds to the epithelial attachment (zone A), while the lowest indices correspond to the epithelium of the attached gingiva and the alveolar mucosa (D and $\mathrm{E}$ ).

The inflammatory indices (II) corresponding to the subzones $\left(A_{1}, A_{2}\right.$ and $\left.A_{3}\right)$ are listed in Table 6. The most severe inflammation was found adjacent to the middle third of the epithelial attachment $\left(\mathrm{A}_{2}\right)$.

The difference in II between the connective tissues underlying the epithelial attachment and under the crevicular epithelium is statistically significant according to Table $7(p<.001)$ and so is the difference between the crevicular and outer surface of the free gingiva.

As seen in Table 8 the connective tissue underlying the crevicular one third of the epithelial attachment $\left(A_{1}\right)$ had a significantly higher degree of inflammation than the apical one third of the epithelial attachment $(p<.05)$. However, the middle one third showed a significantly higher inflammatory index than both the crevicular and the apical one third of the epithelial attachment.

\section{SIGNIFICANCE}

Since the radioactive indices (RAI) in the present paper are based on basal cells only, the results show high values which are not directly comparable to other papers where the entire thickness of the epithelium has been included in the cell counts. ${ }^{13}, 15$

The RAI indices in this paper cannot be used for compulation of turnover or renewal time of the epithelium by the commonly used formulae since these also are based on counting the total number of epithelial cells overlying the basal cells. However, confining our index to the basal cell layer provides a much more meaningful
TABLE 1

Radioactive Index (R.A.I.) of Gingival and Alveolar Mucosal Epithelium

\begin{tabular}{lccc}
\hline \multicolumn{1}{c}{ Zones } & Means & $\begin{array}{c}\text { Standard } \\
\text { Deviations }\end{array}$ & $\begin{array}{c}\text { Standard } \\
\text { Errors }\end{array}$ \\
\hline A $\begin{array}{l}\text { Epithelial } \\
\text { Attachments }\end{array}$ & 13.41 & 10.21 & 0.87 \\
\hline B $\begin{array}{l}\text { Crevicular } \\
\text { Epithelium }\end{array}$ & 19.65 & 8.05 & 0.68 \\
\hline C $\quad \begin{array}{l}\text { Free Gingival } \\
\text { Surface }\end{array}$ & 16.91 & 8.62 & 0.76 \\
\hline D $\quad \begin{array}{l}\text { Attached } \\
\text { Gingiva }\end{array}$ & 7.90 & 3.82 & 0.33 \\
\hline E $\quad \begin{array}{l}\text { Alveolar } \\
\text { Mucosa }\end{array}$ & 14.67 & 5.42 & 0.47 \\
\hline A and B & 16.53 & 9.69 & 0.58 \\
\hline C and D & 12.30 & 7.99 & 0.49 \\
\hline A, B, C and D & 14.48 & 9.15 & 0.39 \\
\hline A, B, C, D and E & 14.51 & 8.54 & 0.33 \\
\hline
\end{tabular}

TABLE 2

R.A.I. Means of Subzones of Zone A (The Epithelial Attachment)

\begin{tabular}{cccc}
\hline Subzone & Mean & S.D. & S.E. \\
\hline $\mathrm{A}_{1}$ & 15.46 & 11.75 & 1.03 \\
\hline $\mathrm{A}_{2}$ & 13.08 & 12.73 & 1.12 \\
\hline $\mathrm{A}_{3}$ & 8.28 & 10.93 & 0.96 \\
\hline
\end{tabular}

TABLE 3

Analysis of Between Zones Differences of the R.A.I. Means

\begin{tabular}{lcccc}
\hline Zones & Means & Difference & $F$ & $P$ \\
\hline B - A & $19.65-13.41$ & 6.24 & 31.72 & $\mathrm{p}<.001$ \\
\hline B - C & $19.71-16.77$ & 2.94 & 9.78 & $\mathrm{p}<.01$ \\
\hline C - D & $16.59-8.18$ & 8.41 & 95.33 & $\mathrm{p}<.001$ \\
\hline E - D & $14.62-7.88$ & 6.74 & 203.04 & $\mathrm{p}<.001$ \\
\hline
\end{tabular}

TABLE 4

Analysis of Between Subzone Differences of the R.A.I.

\begin{tabular}{lccc}
\hline & \multicolumn{3}{c}{ Radioactive Index $(R . A . I)}$. \\
\cline { 2 - 4 } Subzones & Means & Difference & $P$ \\
\hline$\overline{\mathrm{A}}_{1}-\overline{\mathrm{A}}_{3}$ & $15.46-8.28$ & 7.18 & $\mathrm{p}<.001$ \\
\hline$\overline{\mathrm{A}}_{2}-\overline{\mathrm{A}}_{3}$ & $13.08-8.28$ & 4.80 & $\mathrm{p}<.001$ \\
\hline$\overline{\mathrm{A}}_{2}-\overline{\mathrm{A}}_{1}$ & $15.46-13.08$ & 2.38 & $\mathrm{p}<.05$ \\
\hline
\end{tabular}


TABLE 5

Inflammatory Index (I.I.) of Connective Tissues Of Gingiva and Alveolar Mucosa Corresponding to the Epithelial Zones (Fig. 1)

\begin{tabular}{lrrr}
\hline Zones & Mean & S.D. & S.E. \\
\hline A & 35.42 & 20.52 & 1.75 \\
\hline B & 25.44 & 16.66 & 1.42 \\
\hline C & 10.50 & 13.14 & 1.16 \\
\hline D & 5.98 & 7.74 & 0.67 \\
\hline E & 4.07 & 6.07 & 0.53 \\
\hline A and B & 30.43 & 19.31 & 1.16 \\
\hline C and D & 8.20 & 10.95 & 0.67 \\
\hline A,B,C, and D & 19.58 & 19.31 & 0.83 \\
\hline A,B,C,D and E & 16.51 & 18.56 & 0.71 \\
\hline
\end{tabular}

TABLE 6

I.I. Means of Subzones of Zone A

\begin{tabular}{cccc}
\hline Subzone & Mean & S.D. & S.E. \\
\hline $\mathrm{A}_{1}$ & 36.02 & 21.05 & 1.85 \\
\hline $\mathrm{A}_{2}$ & 38.87 & 24.88 & 2.19 \\
\hline $\mathrm{A}_{3}$ & 31.75 & 26.21 & 2.31 \\
\hline
\end{tabular}

TABLE 7

Analysis of Between Zone Differences of the I.I. Means

\begin{tabular}{lcccc}
\hline Zones & Means & Difference & $F$ & $P$ \\
\hline A - B & $35.42-25.44$ & 9.98 & 52.09 & $\mathrm{p}<.001$ \\
\hline B - C & $25.05-10.51$ & 14.54 & 138.99 & $\mathrm{p}<.001$ \\
\hline C - D & $10.60-5.47$ & 5.13 & 27.22 & $\mathrm{p}<.001$ \\
\hline D - E & $6.00-4.79$ & 1.21 & 1.31 & $\mathrm{p}<.05$ \\
\hline
\end{tabular}

TABLE 8

Analysis of Between Subzone Differences of I.I.

\begin{tabular}{lccc}
\hline Subzones & Means & Difference & $P$ \\
\hline$\overline{\mathrm{A}}_{1}-\overline{\mathrm{A}}_{3}$ & $36.02-31.75$ & 4.27 & $\mathrm{p}<.05$ \\
\hline$\overline{\mathrm{A}}_{2}-\overline{\mathrm{A}}_{3}$ & $38.87-31.75$ & 7.12 & $\mathrm{p}<.001$ \\
\hline$\overline{\mathrm{A}}_{2}-\overline{\mathrm{A}}_{1}$ & $38.87-36.02$ & 2.85 & $\mathrm{p}<.05$ \\
\hline
\end{tabular}

basis for comparison of the premitotic activity in the progenitor cell areas of the various zones of the gingival epithelia than previous methods, and the relationship of epithelial proliferation to inflammation becomes

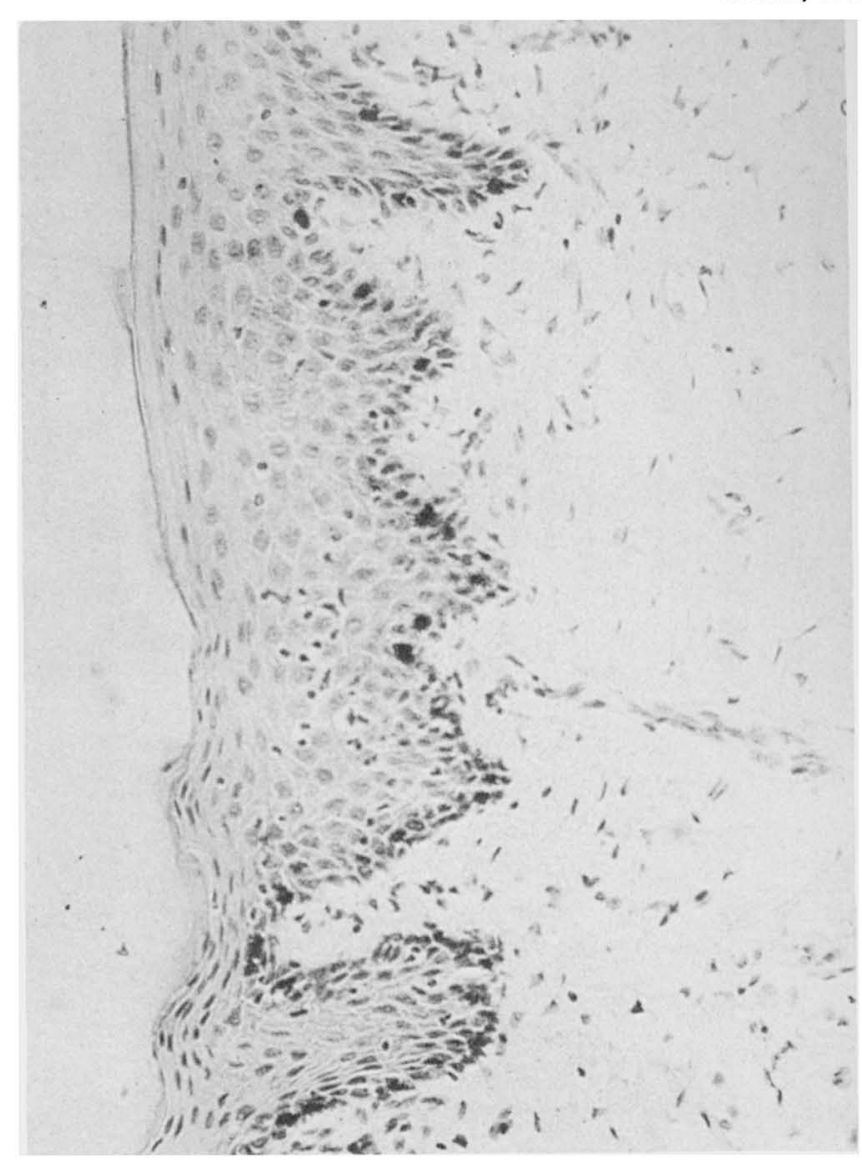

FIGURE 4. The junction between the attached gingiva which is keratinized (top two thirds) and the alveolar mucosa (bottom one third of photomicrograph) non keratinized. (Original magnification $\times 200$ ).

more precise when the comparison is confined to the immediately adjacent tissues rather than including a large number of epithelial cells which do not have the potential to proliferate.

That the epithelial attachment has approximately twice the premitotic activity of the attached gingival epithelium is in accordance with previous reports. ${ }^{4,34,35}$ Higher activity in the crevicular epithelium than in the epithelial attachment has also been reported by others. ${ }^{36}$

In contrast to previous reports, ${ }^{37}$ the surface epithelium of the free gingiva showed higher activity than the epithelial attachment.

The difference in premitotic labeling between the alveolar mucosa and the attached gingival epithelium was very obvious, and directly related to the well defined anatomical landmarks between these two zones (Figure 4). Such well defined demarkations were not observed for any of the other zones.

It has often been assumed ${ }^{1,2}$ that the relatively high RAI in the crevicular epithelium and the epithelial attachment (Figure 5) may be related to irritation and inflammation in the underlying connective tissues; and 


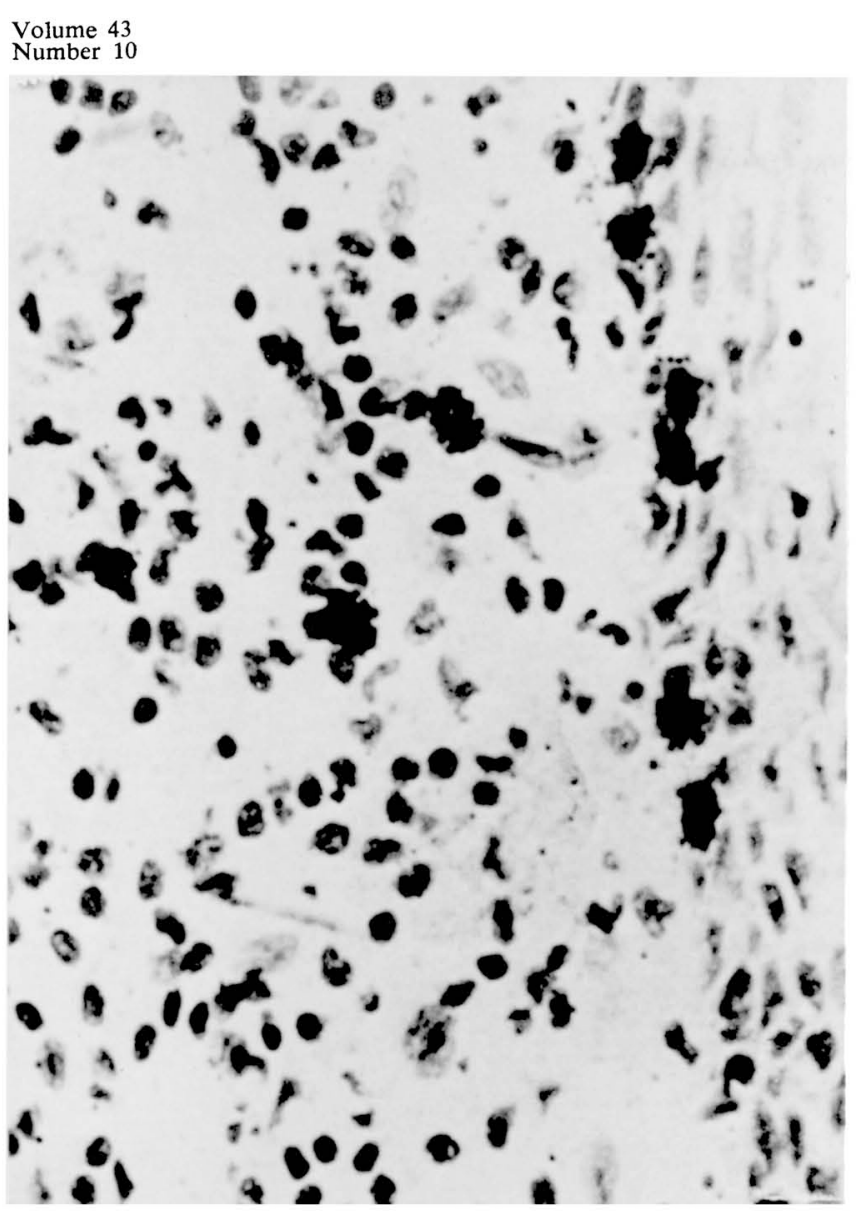

FIGURE 5. Intermediate one third of the epithelial attachment (Zone $\mathrm{A}_{2}$ ). Heavy labeling of basal cells and moderate to severe inflammation. Original magnification $\times 780$ ).

that the low RAI in the epithelium of the attached gingiva may be an expression of a lack of irritation and inflammation at the surface of the attached gingiva. ${ }^{3}$

Such assumptions have been based on subjective evaluations of microscopic fields without means of quantitating inflammation, or by examining inflamed and non inflamed samples of gingival tissues. ${ }^{20}$ Inflammatory cells within the gingival epithelium have been counted, ${ }^{18}$ but this does not include the origin of the inflammatory reaction in the connective tissues.

In spite of obvious shortcomings (no evaluation of biochemical and humoral aspects of inflammation), the inflammatory index (II) used in this paper, represents a method of quantitating chronic inflammation on the basis of the relative number of inflammatory cells which to a known extent characterize the degree of severity of inflammation. ${ }^{38}$ No effort was made to differentiate specific types of inflammatory cells, since such differentiation would complicate the final analysis of results without available knowledge on how to assess the significance of such differentiation.

The inflammatory index is particularly useful for precise location of inflammation and comparison be-

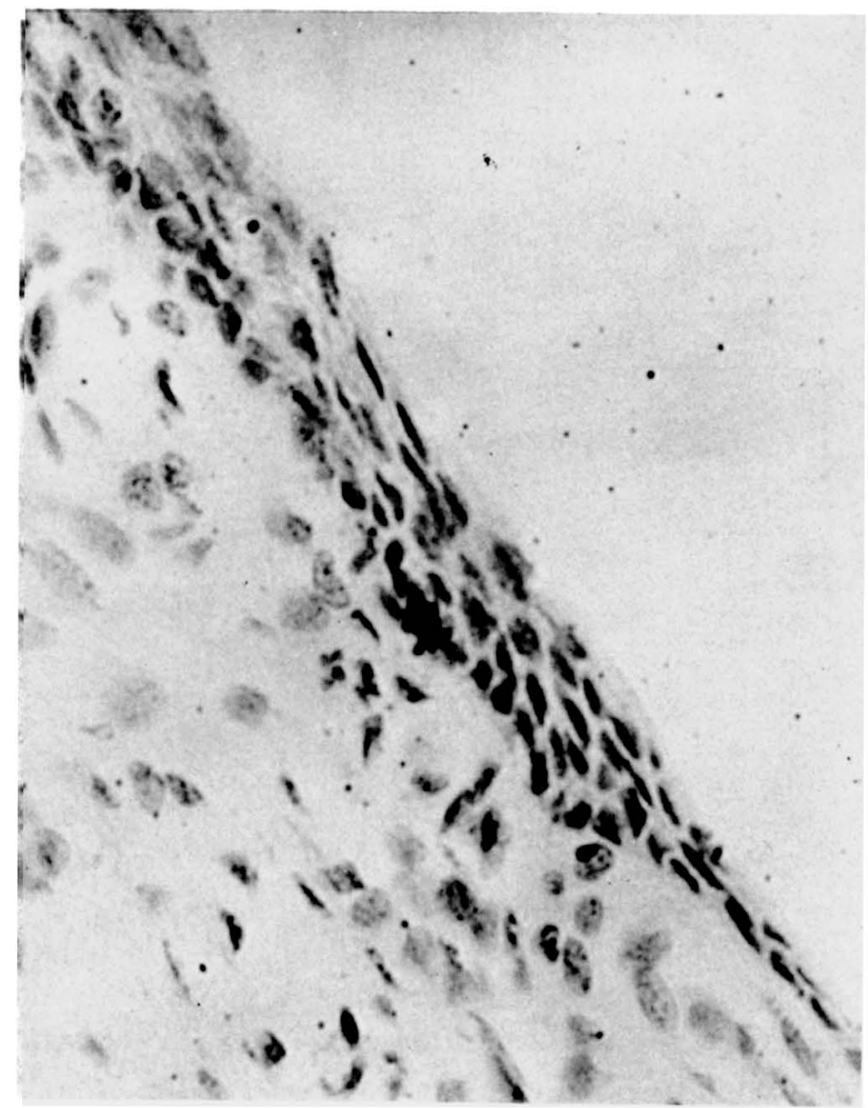

FIGURE 6. Apical one third of the epithelial attachment (Zone $A_{3}$ ). Low labeling index and minimal inflammation. (Original magnification $\times 780$ ).

tween epithelial labeling and inflammatory reaction in adjoining tissues. Only a narrow zone (one half of the microscopical aperture $\times 1000$ ) of connective tissues adjacent to the epithelium was included in the indexing and this often meant that the entire spread of inflammation was not included, while in other instances only part of the field included inflammatory cells. The random occurrance of this variation in distribution of inflammatory cells should however assure a fair estimate of general intensity of inflammation when a large number of fields are counted.

This detailed study of the location of inflammation established that in mild chronic gingivitis the most severe inflammation occurred corresponding to the middle and crevicular one third of the epithelial attachment (Figure 5), with significantly less inflammation at the apical one third of the epithelial attachment (Figure 6). The location of the inflammatory cells is probably related to the spread of irritants in the interstitial tissue spaces between the collagen fibers, and with a good part of the free gingival fibers arranged approximately parallel to the tooth surface it is natural that the inflammation will spread apically to the base of the clinical gingival crevice. The claimed ${ }^{3}, 15,39$ direct relationship between severity of gingival inflammation 
TABLE 9

Correlation Coefficients (r) Between R.A.I., I.I. of the Different Zones

\begin{tabular}{lcccc}
\hline Zone & \multicolumn{5}{c}{ R.A.I. and I.I. } \\
\cline { 2 - 5 } & $\begin{array}{c}\text { Microscopic } \\
\text { Fields } \\
\text { Examined }\end{array}$ & $r$ & $t$ & $p$ \\
\hline $\mathrm{A}$ & 712 & -0.047 & -1.25 & $\mathrm{p}>.05$ \\
\hline $\mathrm{B}$ & 349 & -0.128 & -2.39 & $\mathrm{p}<.05$ \\
\hline $\mathrm{C}$ & 369 & 0.120 & 2.29 & $\mathrm{p}<.05$ \\
\hline $\mathrm{D}$ & 1,123 & 0.106 & 3.53 & $\mathrm{p}<.001$ \\
\hline $\mathrm{E}$ & 395 & -0.039 & -0.78 & $\mathrm{p}>.05$ \\
\hline $\mathrm{AB}$ & 1,061 & -0.103 & -3.36 & $\mathrm{p}<.001$ \\
\hline $\mathrm{CD}$ & 1,492 & 0.166 & 6.46 & $\mathrm{p}<.001$ \\
\hline $\mathrm{ABCD}$ & 2,553 & 0.115 & 5.83 & $\mathrm{p}<.001$ \\
\hline $\mathrm{ABCDE}$ & 2,948 & 0.088 & 4.73 & $\mathrm{p}<.001$ \\
\hline
\end{tabular}

and mitotic rate in the crevicular epithelium was not substantiated in the present study (Table 9), which does not show any consistent correlation between RAI and II for the various zones of the gingiva and the alveolar mucosa.

If certain zones of the gingiva are selected there appear to be a significant positive correlation between severity of inflammation and RAI at the outer surface of the gingiva $(C, D)$ or the entire gingiva including the epithelial attachment (A,B,C,D) as shown in Table 11. This finding is also true even if the alveolar mucosa is included in the total sample (A,B,C,D,E). Such compiled calculations have apparently been the basis for previous conclusions of positive relationships. However, such conclusion may be misleading because mitotic activity apparently also is related to keratinization and possibly anatomical, physiological and pathological differences between the crevicular epithelial attachment and the surface epithelium other than inflammation.

The low correlation coefficients and the cross over between positive and negative correlation coefficients in the crevicular and epithelial attachment areas (A and $B$, Table 9) and similar findings for the surface of the the gingiva and the alveolar mucosa ( $\mathrm{D}$ and $\mathrm{E}$, Table 9) indicate that no consistent positive correlation was present between premitotic labeling and severity of inflammation. The areas where there was no correlation between RAI and II (crevicular epithelium and alveolar mucosa) or negative correlation (epithelial attachment) were the nonkeratinized areas.

\section{SUMMARY}

The hypothetic correlation between mitotic activity and severity of gingival inflammation was studied in three adult rhesus monkeys with mild chronic gingivitis. Labeling with $\mathrm{H}^{3}$ thymidine was followed by computation of radioactive indices (RAI) for various zones of the gingival epithelium and alveolar mucosa. Severity of inflammation in the areas adjacent to those various epithelial zones was calculated by an inflammatory index (II).

The RAI for epithelial labeling was highest in the crevicular epithelial lining and lowest at the surface of the attached gingiva. The inflammation was most severe under the epithelial attachment, and least severe under the alveolar mucosa and the surface of the attached gingiva. The correlation coefficient between RAI and II values for the combined crevicular epithelium plus the epithelial attachment was $\mathrm{r}=-0.103$ ( $\mathrm{p}<$ $.001)$. There was a positive correlation between RAI and II values for the free gingiva plus the attached gingiva $r=0.166$, $(p<.001)$. There was no significant correlation between RAI and II for the alveolar mucosa $r=-0.039(p>.05)$. For the total number of observations the correlation coefficient was $r=0.088$ $(\mathrm{p}<.001)$.

No consistent pattern of correlation between premitotic labeling and severity of inflammation was found.

\section{CONCLUSION}

Mitotic activity in the gingiva and the alveolar mucosa is not directly related to the degree of inflammation in the adjacent connective tissues.

\section{ACKNOWLEDGEMENTS}

The administration of the isotopes was by Dr. Carlos E. Nasjleti, and the histologic sections and radioautographs were prepared by Jean I. Simmons and Virginia W. Hartog at the Veterans Administration Hospital, Ann Arbor, Michigan.

\section{REFERENCES}

1. Marwah, A. S., Weinmann, J. P. and Meyer, J.: Effect of Chronic Inflammation on the Epithelial Turnover of the Human Gingiva. A.M.A. Arch. Path., 69:147-153, 1960.

2. Skougaard, M. R.: The Renewal of Gingival Epithelium in Monkeys Studied by Means of Radioisotopes. Tandlaegebladet, 69:863-872, 1965.

3. Mühlemann, H. R. and Hartl, S. T.: Daily Variations of Mitotic Rate and Inflammatory Cell Migration in the Epithelium of the Intermolar Rat Papilla. Bull. Schweiz. Akad. Mediz, Wissensch., 11:379-385, 1955.

4. Meyer, J., Marwah, A., and Weinmann, J.: Mitotic Rate of Gingival Epithelium in Two Age Groups. J. Invest. Dermat., 27:237-247, 1956.

5. McHugh, W. D.: The Development of the Gingival Epithelium in the Monkey. (Abstr.) J. Dent. Res., 38:1215, 1959.

6. Meyer, J., Medak, J. and Weinmann, J. P.: Mitotic Activity and Rates of Growth in Regions of Oral Epithelium Differing in Width. Growth, 24:29-46, 1960. 
7. Hayes, R. L., Silberkweit, M., and Soni, N. N., and Simpson, T. H.: Pattern of Mitotic Activity and Cell Densities in Normal Gingival Epithelium of Children, J. Dent. Res., 43:217-223, 1964.

8. Soni, N. N., Silberkweit, M. and Hayes, R. L.: Pattern of Mitotic Activity and Cell Densities in Human Gingival Epithelium. J. Periodont., 36:15-21, 1965.

9. Henry, J. L., Meyer, J., Weinmann, J. P and Schour, I.: Pattern of Mitotic Activity in Oral Epithelium of Rabbits. A.M.A. Arch. Path., 54:281-297, 1952.

10. Hansen, E. R.: Mitotic Activity and Cell Densities in the Gingival Epithelium of Rats. Odont. Tdsk., 75:28-32, 1967.

11. Messier, B. and Leblond, C. P.: Cell Proliferation and Migration as Revealed by Autoradiography after Injection of Thymidine $\mathrm{H}^{3}$ into Male Rats and Mice. Am. J. Anat., 106:247-285, 1960.

12. Beagrie, G. S., and Skougaard, M. R.: Observations of the Life Cycle of the Gingival Epithelial Cells of Mice as Revealed by Autoradiography. Acta Odont. Scand., 20:15-31, 1962.

13. Skougaard, M. R. and Beagrie, G. S.: The Renewal of Gingival Epithelium in Marmosets (Callithrix Iacchus) as Determined through Autoradiography with $\mathrm{H}^{3}$. Acta. Odont. Scand., 20:467-484, 1962.

14. Toto, P. D., and Ojha, G.: Generation Cycle of Oral Epithelium in Mice. J. Dent. Res., 41:388-391, 1962.

15. Dimassimo, C.: Proliferation and Migration of Cells in the Gingival Epithelium. Rochester, New York University, 1963 . III +58 p. typed thesis.

16. Dhawan, A. S. and Toto, P. D.: Renewal of Cell Population in Palate and Tongue Epithelia of Mice. J. Dent. Res., 44:989-995, 1965.

17. Hansen, E. R.: Mitotic Activity in the Oral Epithelium of the Rat. Variation According to Age and Time of Day. Odont. Tdsk., 74:196-201, 1966.

18. Fehr, C. and Mühlemann, H. R.: Distribution and Degree of Inflammatory Cell Infiltration in the Epithelium of the Interdental Papilla of the Rat Molar. Parodontologie, 8:159-163, 1953.

19. Marwah, A. S., Weinmann, J. P. and Meyer, J.: Effect of Chronic Inflammation on the Epithelial Turnover of the Human Gingiva. Am. J. Anat., 104:381-402, 1959.

20. Weiss, M. D., Weinmann, J. P. and Meyer, J.: Degree of Keratinization and Glycogen Content in the Uninflamed and Inflamed Gingiva and Alveolar Mucosa. J. Periodont., 30:208-218, 1959.

21. Glickman, I., Petralis, R. and Marks, R. M.: The Effect of Powered Toothbrushing and Interdental Stimulation Upon Microscopic Inflammation and Surface Keratinization of the Interdental Gingiva. J. Periodont., 38:108111,1965

22. Irons, W. B. and Schaffer, E. M.: Circadian
Rhythms in the Oral and Gingival Epithelium of the Rat. Periodontics, 4:316-321, 1966.

23. Marwah, A., Meyer, J., and Weinmann, J. P.: Mitotic Rate of Gingival Epithelium in Two Age Groups. J. Periodont. 27:313, 1956.

24. Halberg, F., Zander, H. A., Houghlum, M. W., and Mühlemann, H. R., Daily Variations in Tissue Mitoses, Blood Eosinophils and Rectal Temperatures of Rats. Am. J. Phys., 177:361-366, 1954.

25. Mühlemann, H. R., Ebneter, M. and Rupf, W.: Diurnal Variation in Mitotic Activity of Oral and Corneal Epithelium in Colchicinized Albino Rats. Helv. Odont. Acta, 3:30-34, 1959.

26. Messier, B. and LeBlond, C. P.: Preparation of Coated Radioautographs by Dipping Sections in Fluid Emulsion. Soc. Exper. Biol. Med. Proc., 96:7-10, 1957.

27. Joftes, D. L.: Liquid Emulsion in Autoradiography with Tritium. Lab. Invest., 8:131-138, 1959.

28. Engler, W. O. The Development of the Epithelial Attachment in the Rhesus Monkey. Ann Arbor, University of Michigan, School of Dentistry, 1964. VIII + 107 p. typed thesis.

29. Engler, W. O., Ramfjord, S. P., and Hiniker, J. J.: Development of Epithelial Attachment and Gingival Sulcus in Rhesus Monkeys. J. Periodont., 36:44-57, 1965.

30. Stone, S.: Repair and Regeneration in the Gingival Sulcus Following Scaling and Curettage in the Rhesus Monkey. Ann Arbor, University of Michigan, School of Dentistry, 1965 . VII +125 p. typed thesis.

31. Stone, S., Ramfjord, S. P., and Waldon, J.: Scaling and Gingival Curettage. A Radioautographic Study. J. Periodont., 37:415-430, 1966.

31. Caffesse, R. G.: Reverse Bevel Periodontal Flaps in Rhesus Monkeys. Ann Arbor, University of Michigan, School of Dentistry, 1967. VIII + 97 p. typed thesis.

33. Orban, B.: Clinical and Histologic Study of the Surface Characteristics of the Gingiva. Oral Surg., Oral Med., and Oral Path., 1:827-841, 1948.

34. Greulich, R. C.: Epithelial D. N. A. and R. N. A. Synthesis Activities of the Gingival Margin. (Abstr.) J. Dent. Res., 40:682-683, 1961.

35. Cutright, D. E., and Bauer, H.: Cell Renewal in the Oral Mucosa and Skin of the Rat. I. Turnover Time. Oral Surg., Oral Med., and Oral Path., 23:249-259, 1967.

36. Löe, Harald: Physiologic Aspects of the Gingival Pocket. An Experimental Study. Acta Odont. Scand., 19: 387-395, 1961.

37. Trott, J. R. and Gorenstein, S. L.: Mitotic Rates in the Oral and Gingival Epithelium of the Rat. Arch. Oral Biol., 8:425-434, 1963.

38. Robbins, S. L.: Textbook of Pathology. W. B. Saunders Co., Philadelphia, 2nd edition, 1964.

39. McHugh, W. D. and Zander, H. A.: Cell Division in the Periodontium of Developing and Erupted Teeth. Dent. Pract., 15:451-457, 1965. 